\title{
PRESENCE OF THE GASTRONOMIC FRANCHISE CHAINS IN POLAND
}

\author{
EDYTA GHERIBI
}

RECEIVED

ACCEPTED

JEL

CLASSIFICATION

KEYWORDS

ABSTRACT
University of Lodz, POLAND

e-mail: edyta.gheribi@uni.lodz.pl

28 January 2016

1 June 2016

M55

franchising, management, business models, catering, companies, gastronomy

The aim of this paper is to present the gastronomic franchise chains in Poland. This paper presents the development of the gastronomic market in Poland and the development of franchise chains in this sector. Despite the decreasing total number of catering establishments, the number of restaurants in 2014 increased by $16,58 \%$ compared to 2010. The sector is growing and attracting new investments and good future perspectives are foreseen. Restaurants constitute the most lucrative segment of the catering market, generating almost $60 \%$ of the sector's aggregate values. The catering industry, and in particular the fast food sector, have been key areas for business format franchising. Franchising is growing in significance in Europe and internationally. Consequently, franchising has become an established way of carrying out business. The number of catering brands that want to operate in the Polish market and develop through franchising programmes is still on the rise. Economy of scale is the main reason why entrepreneurs decide to cooperate in franchising regardless of the situation of the market, eg. in the form of better conditions of supply. Analysts forecast further expansion of restaurant facilities and gastronomic franchise chains especially in shopping malls, city centers, high streets and along important communication routes.

\section{Introduction}

Franchising represents a mode of organisation that can be interpreted and understood from the perspective of the theory of the firm. In essence, a business format franchise is concerned with the transference of intellectual property rights that provide access to valuable benefits for both parties to the transaction. The existence of franchising as an organizational form can be explained through two main theories: resource scarcity and agency. The key to any 
successful franchise strategy is that franchisors recognize as an economic imperative the importance of having an ongoing interest in, and relationship with, franchisees. The franchise definition is a continuing relationship in which a franchisor provides a licensed privilege to the franchisee to do business and offers assistance in organizing, training, merchandising, marketing and managing in return for a monetary consideration. Franchising is a form of business by which the owner (franchisor) of a product, service or method obtains distribution through affiliated dealers (franchisees). In exchange for gaining the franchise, the franchisee usually pays the franchisor an initial start-up plus annual licensing fees.

Franchising developed over time as an efficient way to do business and there were versions of franchising employed centuries ago. The origin of the word franchise goes back to Anglo-French, meaning freedom, liberty, and from Middle French, franchir, to free, and earlier from the Old French franc, free.

Franchising has roots in feudal times and the first commercial franchise dealing with sales was Singer Sewing Center, developed by Isaac Singer in 1851 (Fulop, 2000). Singer sold rights to local businessmen to sell his machines and train its users. Singer's model was copied by several companies at the turn of the century. Most early givers of franchise rights did not control the work conditions of the receivers of franchise rights. Although the early receivers of franchise rights could be identified by a common trade name, they were free to create their own business style.

Franchising was employed on a limited basis after the success of Singer's sewing machine distribution method. Business format franchising (the licensing of the brand name/trademarks and of the entire business concept), which is the dominant mode of franchising today, came onto the economic scene after World War II and the subsequent baby boom. There was an overwhelming need for all types of products and services, and franchising provided a way to quickly grow businesses.

However, all that changed in the 1950, when Ray Kroc reorganised the potential of the franchise cloning to repeat a successful formula and launch the business format of franchise that exists today. Kroc, using the example of McDonald's, devised the concept called "trade dress" to include not only the appearance and the ambient of business décor but also every other business based detail. For Ray Kroc, every aspect of handling McDonald's franchise became a part of a system which ensures that consumer experience in every McDonald's restaurant is the same. Kroc's theory proved to be so successful that soon it had spread in the franchise industry. During the 1960s, gas stations began to accept the unified "trading dress", and standardised their manners of providing service (Love, 1995; Taylor, 2000).

A typical franchise contract from mid-1990 was significantly different from its predecessors in the 1950s and 1960s. That three page contract increased to 50 or more pages and now, the giver of the franchise dictates every aspect of the business relation.

Franchises are a very popular method for people to start a business, especially for those who wish to operate in a highly competitive industry like the fast-food industry. One of the biggest advantages of purchasing a franchise is that you have access to an established company's brand name.

\section{Literature review}

\section{Chapacteristics of catering enterprises in Poland}

In the European Union, including Poland, gastronomy is the largest industry in the hospitality sector. The industry of catering services generates the largest part of value-adding and the majority of jobs in the hospitality sector (Gheribi, 2015). The development of catering services is undoubtedly related to the social and economic changes 
taking place in recent years in our country, the development of civilisation, globalisation, accelerating the pace of life, the invasion of new products and patterns of behavior, change in the economic and socio-demographic in the country, etc (Gheribi, 2013). In Poland during the last 10 years, the conditions of food preparation and consumption have changed significantly (Gheribi, 2013). As Poles are changing their lifestyle and tastes and becoming more affluent, they visit restaurants, cafes, pubs or trendy clubs more and more often. The development of the restaurant and hotel industry is closely linked with the evolution of transportation and economic development, which led to the emergence of a new industry - tourism (Knowles, Diamantis, 2004).

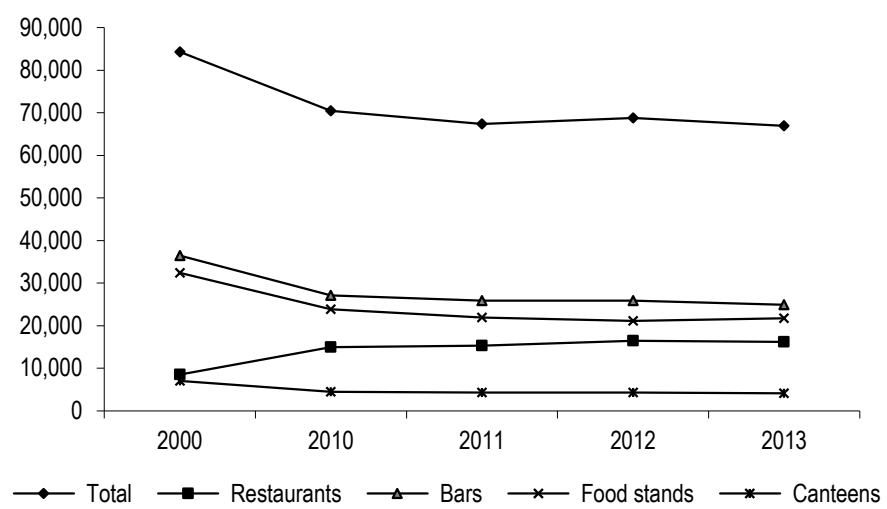

Figure 1. Number of catering establishments in Poland in the years 2000-2014

Source: own calculations based on CSO data, Statistical Yearbook of Poland 2001, 2011, 2012, 2013, 2014, 2015.

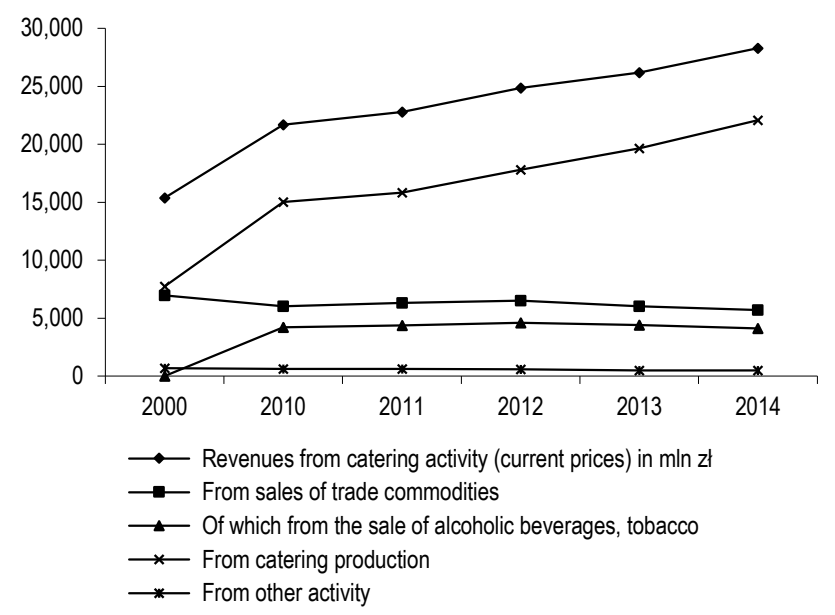

Figure 2. Revenues from catering activity (current prices) in mln zł in Poland in the years 2000-2014

Source: own calculations based on CSO (GUS) data, Statistical Yearbook of Poland 2001, 2011, 2012, 2013, 2014, 2015. 
Gastronomy is ones of the most vigorous sectors of the Polish economy. The catering market in Poland is relatively young and has a lot of potential. This sector in Poland is a quickly developing branch of the national economy. One of the indicators characterising the development of catering establishments is a number of these enterprises (Figure 1). According to CSO data in 2014 there 66,345 catering establishments, compared to 66,966 in 2013. According to the CSO data, the number of catering enterprises gradually increased in Poland in the period of 2000-2007 (the economic boom period) and after 2007 gradually decreased (the economic crisis period). The economic crisis has not spared any sector in Poland. Still, catering was able to overcome it much better than other industries. The number of restaurants increased every year since analysis began in 2010. A major element that shows the increased catering market is the systematically growing revenue. The revenue of catering establishments is generated mainly by own food production, followed by alcohol and tobacco sales. It is important to stress that the revenue generated by own food production has been rapidly increasing. In 2014, own production generated $78.05 \%$ of total catering activity revenue (Figure 2). Poland's restaurant market may have reached, according to preliminary estimates, the value of some PLN 24.2 bn, data included in researcher PMR's report "HoReCa Market in Poland 2014" (Frontczak, 2014). Poland's restaurant market is growing on average by $2-3 \%$ annually. According to CSO data, in 2014 the revenue was $28,272.8 \mathrm{mln} \mathrm{zl}$, and this was increased by $30.39 \%$ compared to 2010 .

Changing dietary habits, especially among the younger generation, has support market growth. The report "Poland on a plate 2015" drafted by Makro Cash \& Carry (2015), which surveys Poles' eating habits each year, indicates that among the youngest adult age group (18-24 years of age) the percentage of people eating out at least once a week amounts to $63.9 \%$.

\section{Method}

The paper uses secondary sources of information such as statistical data of the CSO (Statistical Yearbooks), business reports (Reports on franchising in Poland), and industry newsletters and others publications. The research period was the years 2000-2015. A comparative method was applied for the analysis of collected data and materials.

\section{Results}

\section{Gastronomic franchise chains in Poland}

The catering industry, and in particular the fast food sector, have been key areas for business format franchising. Franchising is growing in significance in Poland. Consequently, franchising has become an established way of carrying out business. Although by no means a new concept, business format franchising has become an established global enterprise trend within the service sector, in general, and specifically within the catering services sector. It represents a popular method of financing the expansion of multi-site chains that deliver a consistent service concept and is a strategy adopted by franchisees to take advantage of a more entrepreneurial management system.

Franchising has been a particularly successful method of business and geographical expansion for the catering market especially for fast food. Companies usually consider franchising or other methods of joint development when they are not capable of expanding as they wish through internal means and when they want to add value to the organisation. The barriers to internal expansion may be associated with a lack of capital, difficulties of acquisition, controlling knowledge or a need for direct control of stock (Ball, 2000; Pokorska, 2004). Disadvantages of franchising fall into three categories: lack of independence, inflexibility, risk associated with the franchisors performance. 
In Poland, the first catering chains emerged in the 90s after the political transformation, and so did McDonald's, Burger King, Pizza Hut and Dunkin Donuts. At the present time, the industry's leading brands all operate internationally and indigenously. But the largest network is still McDonald's.

The number of catering brands that want to operate in the Polish market and develop through franchising programmes is still on the rise. In 2015 more than 1,100 brands (Figure 3) debuted on the Polish franchise market - shown in a Report about franchising in Poland made by Profit system (2016). Most new systems arise in grocery, catering and fashion.

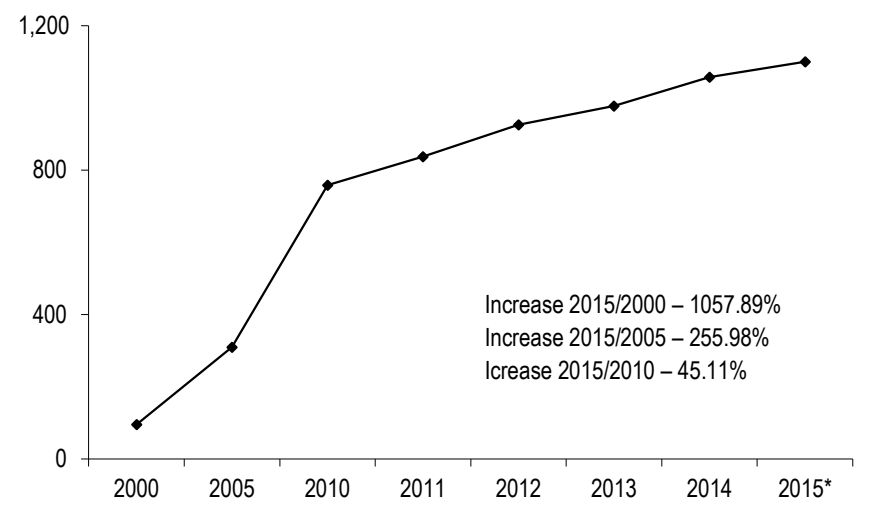

"Forecast.

Figure 3. Number of franchise systems in Poland in 2000-2015

Source: own calculations based on Report on franchising in Poland 2015, Profit System.

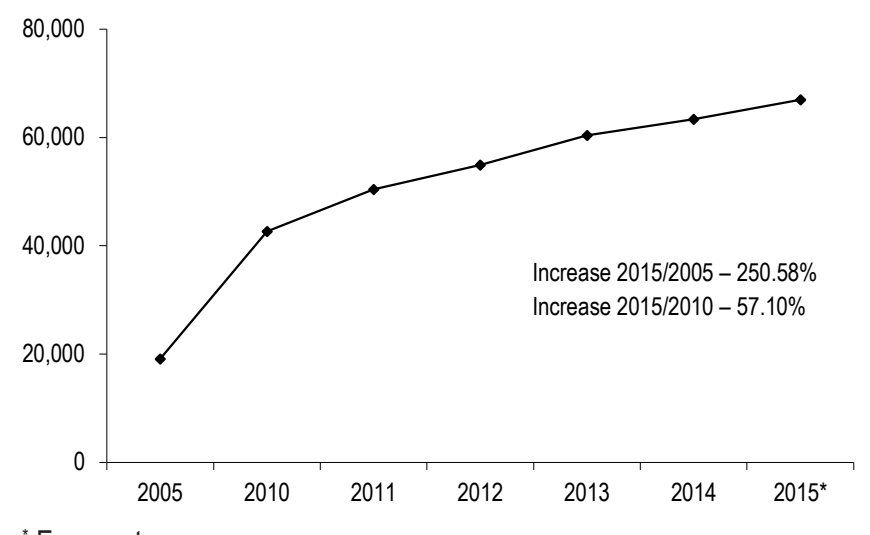

*Forecast.

Figure 4. Number of franchise units in Poland

Source: own calculations based on Report on franchising in Poland 2015, Profit System. 
The past year was another in which the number of franchise systems increased. Facilities run by franchisees increased even faster. This year the number of those companies may exceed 67,000 (Figure 4). Economy of scale is the main reason why entrepreneurs decide to cooperate in franchising regardless of the situation on the market, eg. in the form of better conditions of supply.

Franchisees prefer already proven ideas for restaurants, bistros, and fast food bars. The following chains recorded the biggest number of franchisees: McDonald's, Subway, Noodle w Pudle, Asia to go, Sphinx, Subway and Lody Bonano.

The biggest proven franchising systems include: network of Da Grasso pizzerias (187 franchised establishments), McDonald's (169 franchised establishments), Fornetti (155 franchised establishments), Piwiarnia Warki (78 franchised establishments), and Gruby Benek (77 franchised establishments) (Table 1).

Table 1. The biggest gastronomic chains in Poland in 2015

\begin{tabular}{lccc}
\hline \multicolumn{1}{c}{ Specification } & The number of franchise units & The number of own units & The total number of outlets \\
\hline McDonald's & 247 & 118 & 365 \\
Fornetti & 200 & 54 & 254 \\
Ice-cream Bonano & 217 & 2 & 219 \\
KFC & & 206 & 206 \\
Da Grasso & 200 & 3 & 203 \\
Café Sowa & 139 & 11 & 150 \\
Telepizza & 85 & 30 & 115 \\
Sphinx & 97 & 13 & 110 \\
Biesiadowo & 93 & 7 & 100 \\
Subway & 100 & & 100 \\
Piwiarnie Warka & 78 & 12 & 78 \\
Lody Marsjano & 63 & 70 & 75 \\
Gusto Dominium Pizza & 3 & 67 & 73 \\
Pizza Hut & & & 67 \\
So! Coffee & 54 & 2 & 54 \\
Gruby Benek & 40 & 41 & 42 \\
Café Starbucks & & 10 & 41 \\
Green Way & 24 & 33 & 34 \\
Burger King & & & 33 \\
\hline
\end{tabular}

Source: own calculations.

The biggest franchising chain in Poland for casual dining is operated by Sphinx Polska SA under the "Sphinx" brand. Sphinx allows keeping the franchise:

SPHINX restaurants - the strongest Polish catering brand in one of the largest and most popular restaurant chains in Poland - WOOK restaurant. It is popular and well recognised among customers, belonging to a network that offers authentic Chinese cuisine.

Chłopskie Jadło restaurant - valued by lovers of traditional Polish cuisine.

The most popular franchise licenses can be found in the category of confectionaries, cafes and ice-cream shops. This segment also takes the lead in terms of the number of establishments but this is attributed mostly to 
two chains: Fornetti minibakeries and Alois Dallamyr vending chain. Achieving success is especially difficult in the market of cafes where the list of competitors includes such brands as Grycan or Costa by Coffee Heaven, which have no equal. Attention should also be paid to chains offering sweet cold snacks (ice cream and frozen yoghurts). The leading position belongs to Zielona Budka, which was the first to start franchised ice-cream shops. New concepts have recently bombarded the segment of frozen yoghurts. The Canadian brand Yogen Fruz has reappeared in Poland after two previous unsuccessful attempts and after being absent on the Polish market for a few years.

The smallest number of franchised establishments can be found in the niche segment of healthy cuisine. Healthy food is not able to oust Poles' love for fast food. The biggest chain in this segment is Green Way. The company has started to create a chain of salad bars Vegemania.

The franchises available in gastronomy are relatively rich and everyone can, depending on the amount he or she wishes to spend, choose something for themselves. A whole cross-section of the industry is represented, from low-circulation systems ice cream shops to franchises requiring a candidate to invest an amount of over one million zł. The capital which is necessary to build and open the facility can be divided into franchise systems for:

1. Low capital

Membership includes mostly small catering establishments such as: Ice cream Bonano, Ice Cream Adventure, Ice cream Marsjano, Fornetti, Express Chicken, Biesiadowo, Gruby Benek, Fier Pizza, New York Hot Dog. The necessary equity to open offices in these types of systems is 14-70 thousand zł.

\section{Average capital}

Small self-service food service premises with an area of up to approx. 100 sq.m.

Most of them are companies that specialise in serving pizza egz. Telepizza, Gusto Dominium Pizza, Da Grasso, Pizzeria u Benka, Pijalnia Wódki i Piwa, Piwiarnia Warki, A. Blikle, Berlin Döner Kebap, So! Coffee, Sphinx, Ms Humburger, Sushi to go. The necessary equity to open offices in this type of system is the amount of 100-300 thousand zł.

\section{High capital}

The most capital-intensive gastronomy concepts in the Polish market which offers cooperation on the basis of high investment include McDonald's, Subway, Café Sowa, Green Way, Sushi Bar Nigiri. Apart from their own resources which the potential franchisee must have, the amount of the order is at least 500 thousand $z \nmid$ and more, and furthermore, before implementation of the project the franchisee must pass a series of - sometimes lengthy training but the average return on gastronomy investment in 36 months.

\section{Limitations}

A limitation of the study is the lack of statistics on the number of franchise outlets and the number of franchise systems. The collected data are derived from reports of the companies and the observation of the market and may be flawed.

\section{Conclusions}

In conclusion, we can say that recent decades have seen a dynamic development of catering enterprises in Poland. The catering industry, and in particular the fast food sector, have been key areas for business format franchising. Franchising is growing in significance in Poland. Consequently, franchising has become an established 
way of carrying out business. Although by no means a new concept, business format franchising has become an established global enterprise trend within the service sector, in general, and specifically within the catering services sector. The number of catering brands that want to operate in the Polish market and develop through franchising programmes is still on the rise. The Polish franchise market has been growing continuously for over 10 years, and accelerated its development last year, converging to Western markets. The growing value of the restaurant market in Poland is an opportunity for an even broader development of franchises in the country.

At present, we eat in a restaurant, canteen etc., or at a place "on our way" more and more frequently. In the coming years, an increase in demand for catering services is predicted, taking into consideration the foreseen economic growth and improved financial standing of Polish households. The catering sector is heavily dependent upon disposable incomes. The increase of population wealth and changes in eating habits and lifestyle create a great opportunity and challenge for the development of a wide range of food services. Consequently, the income of the catering businesses will grow.

Despite the fact that the use of catering services in Poland in comparison with developed countries is still low, certainly the demand for eating outside the home in the country will continue to grow.

The development of the catering market and its direction will depend on three main factors of change - socioeconomic, demographic and cultural. The ageing of the baby boom generation, the increase of women entering the workforce, the growing number of active retirees, and the continued increase in the existence of two-income families are creating a demand for services, which franchising is the most logical way to supply.

\section{References}

Ball, S. (2000). Catering. In: C. Lashley, A. Morrison (eds.), Franchising Hospitality Services. Oxford: Butterworth Heinemann. Frontczak, J. (2014). Gastronomia na prostej-gdzie jesteśmy, trendy, nastroje. Food Business Forum. Warszawa.

Fulop, Ch. (2000). In: C. Lashley, A. Morrison (eds.), Franchising Hospitality Services. Oxford: Butterworth Heinemann.

Gheribi, E. (2013). Konsument i przedsiębiorstwo na rynku usług gastronomicznych. Jastrzębie Zdrój: Black Unicorn.

Gheribi, E. (2015). Catering market in Poland. Management and Education, XXI.

Knowles, T., Diamantis, D. \& El-Mourhab, J. (2004). The Globalisation of Tourism and Hospitality. London: Thomson. Love, J.F. (1995). McDonald's: Behind the Arches. Bantam Books.

Makro Cash\&Carry (2015). Polska na talerzu. Raport 2015 Rynek gastronomiczny w Polsce.

Pokorska, B. (2004). Przedsiębiorca w systemie franczyzowym. Warszawa: Agencja Rozwoju Przedsiębiorczości.

Rocznik Statystyczny Polski 2001, 2011, 2012, 2013, 2014, 2015. Warszawa: Główny Urząd Statystyczny.

Taylor, S. (2000). In: C. Lashley, A. Morrison (eds), Franchising Hospitality Services. Oxford: Butterworth Heinemann.

www.arss.com.pl.

www.franchising.pl.

www.portalfranczyza.pl.

Cite this anticle aS: Gheribi, E. (2016). Presence of the gastronomic franchise chains in Poland. European Journal of Service Management, 19 (3), 27-34. DOI: 10.18276/ejsm.2016.19-04. 